\title{
CEO Risk Incentives and Real Earnings Management
}

\author{
Michele Fabrizi ${ }^{1} \&$ Antonio Parbonetti $^{1}$ \\ ${ }^{1}$ Department of Economics and Management, University of Padova, Padova, Italy \\ Correspondence: Michele Fabrizi, Department of Economics and Management, University of Padova, Via del \\ Santo 33, 35123, Padova, Italy. Tel: 39-049-827-3773. E-mail: michele.fabrizi@unipd.it
}

Received: January 2, 2016

Accepted: January 19, 2016 Online Published: February 25, 2016

doi:10.5539/ijbm.v11n3p37

URL: http://dx.doi.org/10.5539/ijbm.v11n3p37

\begin{abstract}
Previous research shows that companies use option compensation to motivate managers to accept risk (Jensen \& Meckling, 1976). Indeed, risk adverse CEOs are likely to accept less risk than that accepted by diversified shareholders (Fama \& French, 1992). Nonetheless, not all risks produce the expected benefits and risk has an intrinsic cost, such as potential large losses, that cannot be eliminated. Therefore, given CEO risk incentives, real earnings management can be viewed as a mechanism used to avoid the undesirable consequences of risk on reported earnings. However, engaging in real earnings management requires cutting investments, such as R\&D, that have a well-documented association with firm's future risk profile (Comin \& Philippon, 2005). As a consequence, the use of real earnings management by CEOs with high-risk incentives as a tool for mitigating the intrinsic costs of risk is an empirical question that we tackle in this paper. Using a sample of quarterly observations from US firms over the period 2003-2010, and an instrumental variable approach to overcome endogeneity concerns, we show that CEOs with high risk-related incentives engage less in real activity manipulations that encompass cutting discretionary expenditures than do executives with low incentives. These findings are consistent with the idea that CEOs incentivized on risk avoid engaging in real management activities that can decrease firm's future risk profile.
\end{abstract}

Keywords: real earnings management, $\mathrm{CEO}$ compensation, earnings management, risk incentives, governance

\section{Introduction}

Risk-neutral shareholders would like executives to undertake all positive net present value projects in order to maximize their wealth but risk averse CEOs accept less risk than that accepted by diversified shareholders (Fama \& French, 1992). In order to align executives' interests with those of shareholders, option compensation is used to motivate CEOs to accept more risk and undertake projects that they would otherwise forego (Jensen \& Meckling, 1976). Academic research has shown that executives respond to such risk-taking incentives. In this line, Coles, Daniel and Naveen (2006) show that higher sensitivity to stock volatility in the managerial compensation scheme gives executives an incentive to both invest in riskier assets and implement more aggressive debt policy. Nonetheless, not all risks undertaken produce the expected benefits. Indeed, there is an intrinsic cost in risk taking activities that cannot be eliminated by managers and some of the risks undertaken by executives in response to risk-based incentives might cause undesirable consequences such as potentially large losses. In this perspective, real earnings management can be viewed as a tool to increase reported earnings and thus mitigate the undesired effects of risk. Indeed, managers engaging in real earnings manipulations make the firm to departure from its normal operational practices in order to mislead at least some stakeholders into believing certain financial reporting goals have been met in the normal course of operations (Roychowdhury, 2006, p. 337).

Previous research has already established that CEOs incentivized on risk engage in income smoothing to avoid wide fluctuations in earnings and to preserve shareholder interests and institutional investor preferences (Grant, Markarian \& Parbonetti, 2009). Nonetheless, whether CEOs incentivized on risk engage in real earnings management activities is ultimately an unexplored empirical research question because two different forces come into play. Specifically, if on one hand, real earnings management can be used by risk-incentivized CEOs to avoid the negative consequences of risk and increase reported performance, on the other hand, it requires cutting discretionary expenditures, such as R\&D, which increase firm's future stock price volatility and have a well-documented association with firm's future risk profile (Comin \& Philippon, 2005). Therefore, this paper analyzes the association between CEOs' risk incentives and real earnings management and aims at understating whether CEOs with high risk incentives use real earnings management to avoid the negative consequences of 
risk on reported earnings.

Using a sample of 4,470 quarterly observations from 1,088 US firms that are likely to have engaged in the earnings game over the period 2003-2010, along with an instrumental variable approach in order to address endogeneity concerns, we focus on the role of CEOs' risk incentives in driving real earnings management decisions. Specifically, we find that CEOs with high risk incentives engage less in real activity manipulations than do executives with low incentives. When we split the real earnings management proxy into its two components-namely, abnormal production costs and abnormal levels of discretionary expenditures- we find evidence of a negative relation only between CEO risk incentives and real earning management through discretionary expenditures. These findings are fully consistent with the idea that CEOs incentivized on risk avoid engaging in real management activities that can decrease firm's future risk profile.

We contribute to both earnings management literature and research on executive compensation. Indeed, to the best of our knowledge, this is the first study to investigate the effect of CEOs' risk incentives on real earnings game strategies. Previous studies (Grant et al., 2009) have documented a positive association between CEO risk incentives and income smoothing while we focus on real manipulations and provide evidence of a negative association between CEOs' incentives and earnings management. Evidences on real activity manipulations are particularly important because the use of real earnings management triggers several concerns since, among all earnings game strategies available to executives to meet/beat targets, it is the most costly option for the firm. Indeed, real earnings management modifies firms' operations, diverting them from their normal courses without an underlying economic reason. Evidence reported in Graham, Harvey, and Rajgopal (2005) indicates that, when executives engage in real earnings management, they burn real cash flows. Moreover, Ge and Kim (2014) show that credit rating agencies and bondholders perceive real earnings management as a credit risk-increasing factor and thus require high risk premiums. In a similar vein, Kim and Sohn (2013) find that the cost of capital is positively associated with the extent of earnings management through the real activities manipulation after controlling for the effect of the accrual-based earnings management. These evidences call for a deep understanding of the incentives that can prevent this managerial practice.

Results documented in the paper have also important practical implications. Graham et al. (2005)'s survey shows that real earnings management is a commonly used practice among executives. Survey results show that the $78 \%$ of the interviewed executives admits to sacrificing long-term value to smooth earnings through real earning management (Graham et al., 2005). Given the widespread use of this value-destroying practice among practitioners and its real effects on firm performance, it is important to understand which incentives can boost or constrain these potentially dangerous actions.

\section{Background}

This paper contributes to research on the role of CEO incentives on affecting earnings management strategies. Extant literature has focused on both non-monetary (Note 1) and monetary CEO incentives.

Kuang, Qin, and Wielhouwer (2014) predict and find that outside CEOs engage in greater income-increasing manipulation in the early years of their tenure. However, the differences in earnings management practices become insignificant after CEOs survive the short run (Kuang et al., 2014). In a similar vein, Choi, Kwak, and Choe (2014) examine the empirical relation between CEO turnover and earnings management and find upward earnings management by the departing CEO only when the departure is forced and the new CEO is an insider. Moving to monetary incentives, Das, Hong, and Kim (2013) find that while CEO bonus on average increases with earnings smoothing, the increase is larger when the firm's cash flow volatility is higher. The authors also document that CEO bonus is shielded from the negative effects of lower earnings arising from the need to report a smoother earnings stream. Cheng and Warfield (2005) find a significantly higher incidence of meeting or just beating analysts' forecasts for firms with higher managerial equity incentives and show evidence consistent with highly incentivized managers selling more shares after earnings management. In a similar vein, Bergstresser and Philippon (2006) document that the use of discretionary accruals to manipulate reported earnings is more pronounced at firms where CEO's potential total compensation is more closely tied to the value of stock and option holding. Duellman, Ahmed, and Abdel-Meguid (2013) show that the opportunist financial reporting effect of equity incentives documented in previous research increases as the monitoring intensity of the firm decreases. Armstrong, Larcker, Ormazabal, and Taylor (2013) measure misreporting using discretionary accruals, restatements, and enforcement actions, and find evidence of a positive relation between vega and misreporting. Although most studies find a positive relation between CEO's monetary incentives and earnings management, Adut, Holder, and Robin (2013) and Gong and Li (2013) do not find evidence of an opportunistic behavior in the presence of high CEO compensation. Specifically, Adut et al. (2013) show that CEO compensation levels are 
positively related to predictive earnings management and negatively related to opportunistic earnings management. Similarly, Gong and Li (2013) find that in companies with higher CEO equity incentives, current year earnings are more informative of future earnings than in other companies. Finally, also Khalil and Simon (2014) find little evidence that earnings management is related to managerial equity ownership.

We contribute to extant research on the relation between CEO incentives and earnings management strategies by analyzing the unexplored link between CEO risk incentives and real earnings management.

Grant et al. (2009) find strong evidence that risk-taking incentives are positively related to measures of income smoothing. Indeed, high levels of perceived risk can negatively affect a manager's tenure and job security (Ronen \& Sadan, 1981; Carlson \& Bathala, 1997), and may harm his/her reputational and human capital. Therefore, CEOs incentivized on risk engage in income smoothing to avoid wide fluctuations in earnings and to preserve shareholder interests and institutional investor preferences (Grant et al., 2009). Real earnings management can be an additional tool used by CEO incentivized on risk to increase reported earnings and mitigate the undesired effects of risk. Nonetheless, in contrast with the earnings management strategies analyzed by previous research, real earnings management encompasses cutting discretionary expenditures such as R\&D that boost firm's future volatility (Comin \& Philippon, 2005). Therefore, if on one hand CEOs incentivized on risk might want to use real earnings management to hide the undesired effects of risk taking, on the other hand they might be unfavorable to using real earnings management because it could decrease firm's future risk profile. Consequently, in this paper we tackle the relation between CEO's risk incentives and real earnings management as an empirical research question.

\section{Variable Measurement}

\subsection{Real Earnings Management}

We build on previous literature to develop our proxies of real earnings management (Roychowdhury, 2006; Cohen, Dey, \& Lys, 2008; Bartov \& Cohen, 2009; Cohen \& Zarowin, 2010; Zang, 2012). Following Zang (2012), we focus on i) reporting a lower cost of goods sold through increased production and ii) decreasing discretionary expenditures (Note 2).

We first generate the normal level of discretionary expenses and production costs using the models developed by Dechow, Kothari, and Watts (1998), as implemented by Roychowdhury (2006). Specifically, we use the following model to estimate the normal level of production costs:

$$
\frac{\operatorname{PROD}_{i, t, q}}{\operatorname{Assets}_{i, t, q-1}}=k_{1} \frac{1}{\operatorname{Assets}_{i, t, q-1}}+k_{2} \frac{\operatorname{SALES}_{i, t, q}}{\operatorname{Assets}_{i, t, q-1}}+k_{3} \frac{\Delta \operatorname{SALES}_{i, t, q}}{\operatorname{Assets}_{i, t, q-1}}+k_{4} \frac{\Delta \operatorname{SALES}_{i, t, q-1}}{\operatorname{Assets}_{i, t, q-1}}+\varepsilon_{i, t, q}
$$

where production costs (PROD) are defined as the sum of cost of goods sold and changes in inventory during the quarter. Abnormal production costs (R_PROD) are defined as actual production costs minus normal production costs, computed using the estimated coefficients from (1).

Second, we model discretionary expenses as a function of lagged sales and estimate the following model to derive normal levels of discretionary expenses:

$$
\frac{\operatorname{DISX}_{i, t, q}}{\operatorname{Assets}_{i, t, q-1}}=k_{1} \frac{1}{\operatorname{Assets}_{i, t, q-1}}+k_{2} \frac{\operatorname{SALES}_{i, t, q-1}}{\operatorname{Assets}_{i, t, q-1}}+\varepsilon_{i, t, q}
$$

Discretionary expenditures (R_DISX) are then defined as actual discretionary expenses minus normal discretionary expenses, computed using the estimated coefficients from (2). We multiply abnormal discretionary expenses by -1 so, as the amount increases, so does the likelihood that the firm is cutting discretionary expenditures.

Following Cohen and Zarowin (2010) and Zang (2012), in order to capture the total effect of real earnings management, we combine the two individual measures into one comprehensive metric of real earnings management (Real EM), by summing together R_PROD and R_DISX.

\subsection{CEOs' Risk Incentives}

We measure CEOs' risk-related incentives (Risk Incentives) using a methodology similar to that used by Rogers (2002, 2005) and Grant et al. (2009), the vega of CEOs' stock options divided by their delta. This approach is also consistent with Core, Guay, and Larcker (2003). We compute CEOs' option vega as the sensitivity of their option holdings to a unit change in stock price volatility using the first derivative of the Black-Scholes option-pricing model in relation to firms' volatility (see Appendix A). The delta is computed by taking the partial derivative of the Black-Scholes equation with respect to stock price. 
In order to estimate the vega and delta of a CEO's option portfolio, we follow Core and Guay's (2002) methodology in dividing the CEOs' options into three groups - options awarded during the year, options awarded in previous years but not yet exercisable, and options granted in previous years and currently exercisable - and computing separate estimates of the delta (Note 4). Core and Guay (2002) show that their proxy captures more than 99 percent of the variation in the value and sensitivity of option portfolio values. Starting from 2006, Execucomp reports all the necessary data for directly computing the vega and delta of CEOs' option portfolios, thus eliminating the need to use Core and Guay's (2002) approximation.

\subsection{Control Variables}

We include in our models several control variables that previous literature has shown influence earnings game strategies (e.g., Zang, 2012).

Equity Incentives controls for CEO's equity incentives that are computed as in Bergstresser and Philippon (2006, 519-520). Specifically, we start by computing the dollar change in the value of executive's stock and option holdings that would come from a 1 percent increase in the company stock price (ONEPCT). Next, as in Bergstresser and Philippon (2006), we standardize ONEPCT by the amount of cash compensation (Note 5) the executive received during the fiscal year.

We proxy CEOs' career concerns using the CEO's age as disclosed in Execucomp. Since older CEOs have fewer career concerns than younger executives do, we create the variable Career Concerns, which is equal to the CEO's age multiplied by -1 . Thus, a positive coefficient on Career Concerns indicates that CEOs with high levels of career concerns (younger CEOs) engage more in earnings management than do executives with few career concerns (older CEOs). Log Assets, the natural logarithm of total assets, proxies for the firm's size; Cycle, the length of the operating cycle computed as in Dechow (1994), is an underlying determinant of the variability of working capital; $M_{-} B$, the market value of equity divided by the book value of equity, proxies for growth opportunities; Z Score, Altman's Z-score (Altman, 2000), proxies for a firm's financial health; Market Share is the firm's market share computed as the ratio of the company's total sales to the total sales of its three-digit SIC code industry in a given year quarter; NOA is the firm's net operating assets (i.e., shareholders' equity less cash and marketable securities plus total debt) standardized by total assets; Tenure Auditor is the number of years the auditor has audited the firm; $R O A$ is operating profits divided by total assets; Tenure $C E O$ is a dummy variable that takes a value of 1 if the CEO's tenure is greater or equal to 3 years, and zero otherwise. The use of the tenure dummy is consistent with Fredrickson, Hambrick, and Baumrin (1988), who argue that early vulnerability occurs when the CEO's tenure is three years or less; after three years CEOs start gaining power and becoming entrenched. All variables are winsorized at the $1 \%$ level to mitigate the effect of outliers.

\section{Empirical Analyses}

\subsection{Sample}

Given our focus on the use of earnings game strategies, we test our research question in a setting in which earnings management is likely to occur. Specifically, we restrict our investigation to quarters in which the firm has exactly met analysts' consensus earnings forecasts or has exceeded analysts' expectations by one cent (suspect firms). We focus on analysts' forecasts because Brown and Caylor (2005) show that, in recent years, managers seek to avoid missing quarterly earnings more than missing other targets. We obtain our final sample by merging quarterly information over the period 2003-2010 from three datasets: Execucomp, Compustat, and $\mathrm{I} / \mathrm{B} / \mathrm{E} / \mathrm{S}$. Requiring no missing data for all the variables used in the analysis, excluding firms (see Roychowdhury, 2006) in regulated industries (SIC codes 4400-5000) and banks and financial institutions (SIC codes 6000-6500), and restricting the sample to suspect firms, gives us a final sample of 4,470 firm-quarter observations generated from 1,088 unique firms. Table 1 describes the distribution of observations for fiscal quarters and years. 
Table 1. Sample selection and composition

\begin{tabular}{|c|c|c|c|c|}
\hline \multicolumn{5}{|l|}{ Panel A } \\
\hline \multicolumn{4}{|c|}{ Firm-quarter observations in Compustat (2003-2010) } & 348.998 \\
\hline \multicolumn{5}{|c|}{ minus } \\
\hline \multicolumn{4}{|c|}{ SIC codes from 6000 to 6500 and from 4400 to 5000} & 73.176 \\
\hline \multicolumn{4}{|c|}{ Missing data for computing discretionary accruals } & 99.288 \\
\hline \multicolumn{4}{|c|}{ Missing data for computing real earnings management } & 25.385 \\
\hline \multicolumn{4}{|c|}{ Missing data for computing analysts' guidance } & 98.537 \\
\hline \multicolumn{4}{|c|}{ Missing data for computing CEO incentives } & 24.749 \\
\hline \multicolumn{4}{|c|}{ Missing data for computing control variables } & 818 \\
\hline \multicolumn{4}{|c|}{ No suspect firms } & 22.575 \\
\hline \multicolumn{4}{|l|}{ Final Sample } & 4.470 \\
\hline \multicolumn{4}{|l|}{ Unique firms } & 1.088 \\
\hline \multicolumn{5}{|l|}{ Panel B } \\
\hline Quarter & Freq. & Percent & Cum. & \\
\hline 1 & 1.129 & $25 \%$ & $25 \%$ & \\
\hline 2 & 1.151 & $26 \%$ & $51 \%$ & \\
\hline 3 & 1.061 & $24 \%$ & $75 \%$ & \\
\hline 4 & 1.129 & $25 \%$ & $100 \%$ & \\
\hline Total & 4.470 & $100 \%$ & & \\
\hline \multicolumn{5}{|l|}{ Panel C } \\
\hline Year & & $\%$ & \% Cum. & \\
\hline 2003 & 835 & $19 \%$ & $19 \%$ & \\
\hline 2004 & 686 & $15 \%$ & $34 \%$ & \\
\hline 2005 & 616 & $14 \%$ & $48 \%$ & \\
\hline 2006 & 427 & $10 \%$ & $57 \%$ & \\
\hline 2007 & 618 & $14 \%$ & $71 \%$ & \\
\hline 2008 & 494 & $11 \%$ & $82 \%$ & \\
\hline 2009 & 410 & $9 \%$ & $91 \%$ & \\
\hline 2010 & 384 & $9 \%$ & $100 \%$ & \\
\hline Total & 4.470 & $100 \%$ & & \\
\hline
\end{tabular}

Note. The table describes the sample selection process and the sample composition.

\subsection{Descriptive Statistics}

Table 2 presents descriptive statistics of the main variables used in the analysis. All values are into reasonable ranges that are comparable with the ranges in previous studies. Specifically, the median (mean) vega-to-delta ratio is $0.566(0.637)$, with substantial variability among CEOs. The median CEO age is fifty-five years, and the median tenure is more than three years. The median (mean) incentive ratio is $0.229(0.293)$. Firm characteristics show that our sample (as is it usual when dealing with the Execucomp database) is made up of large, profitable firms with high growth opportunities.

Table 2. Descriptive statistics

\begin{tabular}{lrrrrrr}
\hline & N & Mean & SD & p25 & p50 & p75 \\
\hline R_PROD & 4.470 & $-0,023$ & 0,054 & $-0,053$ & $-0,024$ & 0,003 \\
R_DISX & 4.470 & 0,006 & 0,052 & $-0,019$ & 0,003 & 0,026 \\
Real EM & 4.470 & $-0,016$ & 0,097 & $-0,067$ & $-0,022$ & 0,025 \\
Risk Incentives & 4.470 & 0,637 & 0,442 & 0,363 & 0,566 & 0,805 \\
Equity Incentives & 4.470 & 0,293 & 0,226 & 0,122 & 0,229 & 0,396 \\
Career Concerns & 4.470 & $-54,745$ & 7,239 & $-60,000$ & $-55,000$ & $-50,000$ \\
Log Assets & 4.470 & 7,115 & 1,440 & 6,082 & 6,956 & 8,010 \\
Cycle & 4.470 & 119,570 & 72,334 & 67,682 & 105,852 & 154,369 \\
\hline
\end{tabular}




\begin{tabular}{lrrrrrr}
\hline M_B & 4.470 & 3,373 & 2,954 & 1,735 & 2,646 & 4,055 \\
Z Score & 4.470 & 4,876 & 5,293 & 1,895 & 3,292 & 5,887 \\
Market Share & 4.470 & 0,064 & 0,112 & 0,002 & 0,016 & 0,073 \\
NOA & 4.470 & 0,809 & 0,183 & 0,717 & 0,870 & 0,957 \\
Tenure Auditor & 4.470 & 12,429 & 9,014 & 6,000 & 10,000 & 17,000 \\
ROA & 4.470 & 0,015 & 0,021 & 0,007 & 0,015 & 0,025 \\
Tenure CEO & 4.470 & 0,642 & 0,480 & 0,000 & 1,000 & 1,000 \\
\hline
\end{tabular}

Note. The table presents descriptive statistics for the main variables included in the analysis. Variables are defined in Appendix B.

\subsection{Multivariate Analysis}

In our research setting, endogeneity is likely to be an issue because compensation structure and the decision to engage in real earnings management are jointly determined. We assume that the decision to engage in real earnings management can be presented in the following form:

Real Earnings Management $=f\left(\right.$ Risk Incentives, Equity Incentives, Career Concerns, Log Assets, Cycle, $M_{-} B, Z$ Score, Market Share, NOA, Tenure Auditor, ROA, Tenure CEO)

To control for the endogeneity of risk incentives, our research design uses a system of simultaneous equations by adding the following to (A):

$$
\text { Risk incentives }=f(\text { Industry Risk Incentives, Equity Incentives, Career Concerns, Log Assets, Cycle, M_B, Z }
$$
Score, Market Share, NOA, Tenure Auditor, ROA, Tenure CEO)

In this system of simultaneous equations, equation (A) measures the decision to engage in real earnings management, given the CEO's risk incentives. The risk incentives are specified in (B) using as an instrument for CEO's risk incentives of firm $i$ in year $t$, the mean of the risk incentives provided in year $t$ to all CEOs of firms belonging to firm $i$ 's two-digit sic code (Note 6). The underlying logic for using this instrument is that compensation structures tend to be correlated inside given industries (Murphy, 1999), but arguably the industry compensation structure is not related to the reporting strategy of a specific firm. This approach is consistent with previous research using industry-mean values as an instrument for the endogenous variable. For instance, Fabrizi, Mallin and Michelon (2014) use the yearly mean of the equity incentives and bonuses provided to the CEOs of all firms belonging to the 2-digits SIC code of the firm as an instrument for executives' incentives. Similarly, Bozzolan, Fabrizi, Mallin and Michelon (2015) use as an instrument for CSR orientation of firm i in year $t$ the mean of the CSR orientation in year $t$ of all firms belonging to firm is 2-digits SIC code. We estimate equations (A) and (B) through three-stage least square (3SLS) estimates.

Table 3 reports results using Real EM as the dependent variable in equation (A). The negative and (weakly) statistically significant coefficient on CEOs' risk incentives suggest that CEOs with high risk incentives tend to engage less in real earnings management than do executives with low incentives. This result is consistent with the underlying idea that when CEOs are incentivized on risk they avoid cutting discretionary expenditures such as $R \& D$ that might boost firm's future risk profile.

Table 3 asks for further analyses. Indeed, as described in the variable measurement section, Real EM is made up by two different metrics: abnormal production costs (R_PROD) and abnormal levels of discretionary expenditures (R_ DISX). While we expect that risk incentives might negatively affect real earnings management that encompasses cutting discretional expenditure (R_DISX), we do not expect such a relation with abnormal production costs (R_PROD). Therefore, in the next analyses we disentangle Real EM into its two components (R_PROD and R_DISX) and test the impact of CEO's risk incentives on these two real earnings management strategies separately. If our reasoning holds, we expect to see a strong negative relation with CEO' risk incentives and R_DISX but we expect only a weak or non-existing relation between CEO's risk incentives and R_PROD. 
Table 3. CEOs' risk incentives and overall real earnings management

\begin{tabular}{|c|c|c|c|}
\hline & Dependent variable: & Real EM & Incentives \\
\hline & & \multicolumn{2}{|c|}{ 3SLS } \\
\hline & & Eq.A & $E q . B$ \\
\hline \multirow[t]{2}{*}{ Risk Incentives } & & $-0.1622 *$ & \\
\hline & & {$[-1.695]$} & \\
\hline \multirow[t]{2}{*}{ Equity Incentives } & & $-0.1314 * * *$ & $-0.4658 * * *$ \\
\hline & & {$[-2.651]$} & {$[-16.357]$} \\
\hline \multirow[t]{2}{*}{ Career Concerns } & & $-0.0006^{* *}$ & $0.0030^{* * *}$ \\
\hline & & {$[-2.197]$} & {$[3.774]$} \\
\hline \multirow[t]{2}{*}{ Log Assets } & & $0.0156^{* *}$ & $0.0691 * * *$ \\
\hline & & {$[2.264]$} & {$[14.721]$} \\
\hline \multirow[t]{2}{*}{ Cycle } & & $-0.0003 * * *$ & $0.0002 * *$ \\
\hline & & {$[-8.991]$} & {$[2.415]$} \\
\hline \multirow[t]{2}{*}{ M_B } & & $-0.0059^{* * *}$ & 0.0026 \\
\hline & & {$[-11.180]$} & {$[1.287]$} \\
\hline \multirow[t]{2}{*}{ Z Score } & & $0.0013 * * *$ & -0.0016 \\
\hline & & {$[3.441]$} & {$[-1.189]$} \\
\hline \multirow[t]{2}{*}{ Market Share } & & $0.1416^{* * *}$ & -0.0434 \\
\hline & & {$[7.721]$} & {$[-0.777]$} \\
\hline \multirow[t]{2}{*}{$\mathrm{NOA}$} & & $0.1676^{* * *}$ & 0.0098 \\
\hline & & {$[15.538]$} & {$[0.273]$} \\
\hline \multirow[t]{2}{*}{ Tenure Auditor } & & $0.0010^{* * *}$ & $0.0028 * * *$ \\
\hline & & [3.183] & {$[4.431]$} \\
\hline \multirow[t]{2}{*}{ ROA } & & $-0.6703^{* * *}$ & $-2.3035^{* * *}$ \\
\hline & & {$[-2.919]$} & {$[-7.391]$} \\
\hline \multirow[t]{2}{*}{ Tenure CEO } & & $0.0095^{* * *}$ & $-0.0318^{* *}$ \\
\hline & & {$[2.944]$} & {$[-2.568]$} \\
\hline \multirow[t]{2}{*}{ Risk Incentives Industry } & & & $0.6309^{* * *}$ \\
\hline & & & {$[30.698]$} \\
\hline Year Dummies & & YES & NO \\
\hline Quarter Dummies & & YES & NO \\
\hline Industry Dummies & & YES & NO \\
\hline Observations & & 4.470 & 4.470 \\
\hline
\end{tabular}

Note. The table reports 3SLS estimates for equations A, and B. Risk Incentives Industry is the mean of the risk incentives provided in year $\mathrm{t}$ to all CEOs of firms belonging to firm $i$ 's two-digit sic code (excluding firm $i$ ). Variables are defined in Appendix B. *, **, *** indicate statistical significance at $10 \%, 5 \%, 1 \%$ level, respectively. P-values are two tailed. $\mathrm{z}$-statistics in brackets.

Table 4 reports three-stage least-square estimates for equation $\mathrm{A}$ using $R_{-} P R O D$ and $R_{-} D I S X$ as dependent variables. For the sake of brevity, we do not report results from equations B which are similar to those presented in Table 3. Consistent with the idea that CEOs incentivized on risk avoid engaging in real management activities that can decrease firm's future risk profile, Table 4 shows that there is a negative relation only between CEO's risk incentives and R_DISX, while there is no relation with abnormal production costs. This result is fully consistent with our hypothesis and provides further support to the idea that risk incentives act as a constraint in using real earnings management. 
Table 4. CEOs' risk incentives and real earnings management strategies

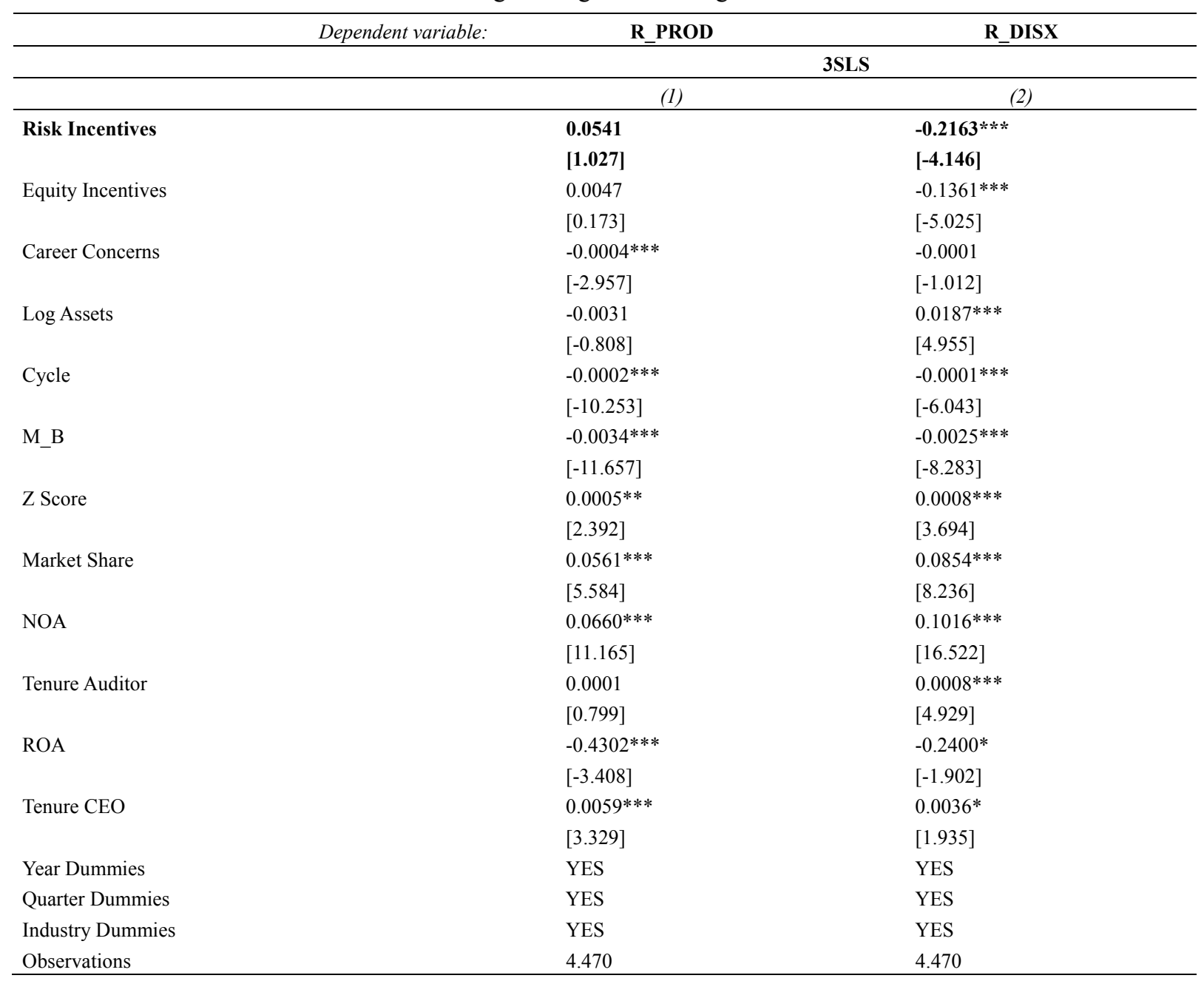

Note. The table reports 3SLS results for equations A simultaneously estimated with equations B (untabulated). Variables are defined in Appendix B. *,**,** indicate statistical significance at $10 \%, 5 \%, 1 \%$ level, respectively. P-values are two tailed. z-statistics in brackets.

\subsection{Alternative Earnings Management Measures}

In this section, we analyze whether results are sensitive to measuring real earnings management in different ways. First, we rank R_DISX and R_PROD into deciles and use the decile distribution of the two real earnings management proxies as dependent variable in equation $\mathrm{A}$. We do so in order to rule out the possibility that results are driven by extreme values in the distribution of the proxies. Results are reported in Columns 1 and 2 in Table 5.

Secondly, since Kothari, Leone, and Wasley (2005) and Cohen, Pandit, Wasley, and Zach (2011) argue that traditional earnings management measures tend to be mis-specified because performance and estimated metrics exhibit a mechanical relation, we used a performance-matched approach. Specifically, for each treatment firm in our sample, we identify a control firm in the same 2-digit SIC code, year and quarter, with the smallest difference in terms of ROA. Then, we compute the real earnings management metric for the treatment firm as the difference in the earnings management proxy between the treatment and control firm. Results are reported in Columns 3 and 4 in Table 5. In both analyses, we find evidence of a significant and negative relation between CEO's risk incentives and abnormal levels of discretionary expenditures, while such a relation is not found with respect to abnormal production costs. 
Table 5. Alternative measures of earnings management

\begin{tabular}{|c|c|c|c|c|}
\hline \multirow[t]{2}{*}{ Dependent variable: } & \multicolumn{2}{|c|}{ Deciles } & \multicolumn{2}{|c|}{ Performance-adj } \\
\hline & R_PROD & R_DISX & R_PROD & R_DISX \\
\hline & \multicolumn{2}{|c|}{ 3SLS } & \multicolumn{2}{|c|}{ 3SLS } \\
\hline & (1) & (2) & (3) & (4) \\
\hline \multirow[t]{2}{*}{ Risk Incentives } & $6.4251 \% *$ & $-6.6827 * *$ & 0.0121 & $-0.1169 * *$ \\
\hline & {$[2.345]$} & {$[-2.401]$} & {$[0.228]$} & {$[-2.329]$} \\
\hline \multirow[t]{2}{*}{ Equity Incentives } & 1.9218 & $-4.7560 * * *$ & -0.0174 & $-0.0832 * * *$ \\
\hline & {$[1.353]$} & {$[-3.298]$} & {$[-0.635]$} & {$[-3.199]$} \\
\hline \multirow[t]{2}{*}{ Career Concerns } & $-0.0283 * * *$ & $-0.0124 *$ & $-0.0003 * *$ & $-0.0002 *$ \\
\hline & {$[-3.891]$} & {$[-1.686]$} & {$[-2.508]$} & {$[-1.852]$} \\
\hline \multirow[t]{2}{*}{ Log Assets } & $-0.4820 * *$ & $0.6331 * * *$ & 0.0001 & $0.0115^{* * *}$ \\
\hline & {$[-2.443]$} & {$[3.160]$} & {$[0.031]$} & [3.194] \\
\hline \multirow[t]{2}{*}{ Cycle } & $-0.0112 * * *$ & $-0.0094 * * *$ & $-0.0002 * * *$ & $-0.0001 * * *$ \\
\hline & {$[-11.267]$} & {$[-9.338]$} & {$[-9.317]$} & {$[-7.784]$} \\
\hline \multirow[t]{2}{*}{ M_B } & $-0.1899 * * *$ & $-0.1268 * * *$ & $-0.0033 * * *$ & $-0.0023 * * *$ \\
\hline & {$[-12.367]$} & {$[-8.165]$} & {$[-11.540]$} & {$[-8.325]$} \\
\hline \multirow[t]{2}{*}{ Z Score } & 0.0172 & $0.0615^{* * *}$ & $0.0005 * *$ & $0.0011^{* * *}$ \\
\hline & {$[1.581]$} & {$[5.598]$} & {$[2.213]$} & {$[5.576]$} \\
\hline \multirow[t]{2}{*}{ Market Share } & $1.6200 * * *$ & $2.8576^{* * *}$ & $0.0621 * * *$ & $0.0734 * * *$ \\
\hline & {$[3.057]$} & {$[5.323]$} & {$[6.170]$} & {$[7.586]$} \\
\hline \multirow[t]{2}{*}{ NOA } & $3.6092 * * *$ & $6.4550 * * *$ & $0.0696^{* * *}$ & $0.0928 * * *$ \\
\hline & [11.552] & {$[20.406]$} & [11.777] & [16.263] \\
\hline \multirow[t]{2}{*}{ Tenure Auditor } & -0.0076 & $0.0182 * *$ & 0.0003 & $0.0005^{* * *}$ \\
\hline & {$[-0.870]$} & {$[2.054]$} & {$[1.502]$} & {$[3.230]$} \\
\hline \multirow[t]{2}{*}{ ROA } & $-12.2497 *$ & -0.1240 & $-0.3597 * * *$ & $-0.6529 * * *$ \\
\hline & [-1.859] & {$[-0.019]$} & {$[-2.841]$} & {$[-5.412]$} \\
\hline \multirow[t]{2}{*}{ Tenure CEO } & $0.2638 * * *$ & 0.0370 & $0.0061 * * *$ & $0.0032 *$ \\
\hline & {$[2.820]$} & [0.391] & [3.449] & {$[1.870]$} \\
\hline Year Dummies & YES & YES & YES & YES \\
\hline Quarter Dummies & YES & YES & YES & YES \\
\hline Industry Dummies & YES & YES & YES & YES \\
\hline Observations & 4.470 & 4.470 & 4.470 & 4.470 \\
\hline
\end{tabular}

Note. The table reports 3 SLS results for equations A simultaneously estimated with equation B (untabulated). Variables are defined in Appendix B. *, *, ** indicate statistical significance at $10 \%, 5 \%, 1 \%$ level, respectively. P-values are two tailed. z-statistics in brackets.

\subsection{Alternative Earnings Management Strategies}

Accounting literature argues that real earnings management is only one out of three strategies available to executive to play the earnings game. Specifically, managers - besides using real earnings management - can also use the managerial discretion left by accounting principles to shift income overtime (Degeorge, Patel, \& Zeckhauser, 1999) or can avoid negative earnings surprises by guiding analysts' forecasts downward (Bartov, Givoly, \& Hayn, 2002; Matsumoto, 2002). Therefore, since the different earnings game strategies are likely to be correlated among them, we check whether results are sensitive to controlling for the other earnings game strategies available to executives, namely accrual-based earnings management and analysts' guidance. We use a cross-sectional model to calculate discretionary accruals where, for each year and quarter, we estimate the normal accrual model for every industry using the Modified Jones Model. This approach, commonly used in earnings management literature (e.g. Cohen \& Zarowin, 2010), partially controls for industry-wide changes in 
economic conditions that affect total accruals, while allowing the coefficients to vary across time. Specifically, we start estimating the following cross-sectional model for each 2 digit SIC/year/quarter group:

$$
\frac{T A_{i, t, q}}{\text { Assets }_{i, t, q-1}}=k_{1} \frac{1}{\text { AsSets }_{i, t, q-1}}+k_{2} \frac{\Delta S A L E S_{i, t, q}}{\text { Assets }_{i, t, q-1}}+k_{s} \frac{P P E_{i, t, q}}{\text { AsSets }_{i, t, q-1}}+\varepsilon_{i, t, q}
$$

In the above model, for fiscal year $t$, quarter $q$, and firm $i$, TA represents the total accruals computed as the difference between i) earnings before extraordinary items and discontinued operations and ii) operating cash flows from continuing operations. Assets represent firm's total assets, $\triangle$ SALES is the change in revenues from the preceding quarter, and PPE is the gross value of property, plant and equipment (Note 7).

The coefficient estimates from (3) are then used to estimate the firm-specific normal accruals (NA) as follows:

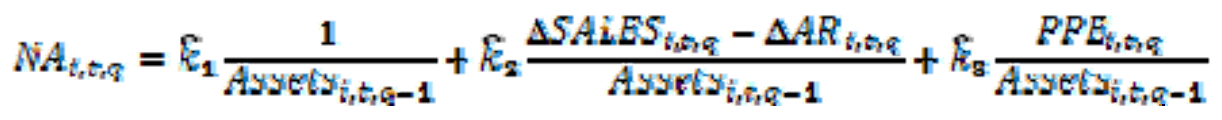

Where $\triangle \mathrm{AR}$ is the change in accounts receivables from the preceding quarter. Finally, we compute discretionary accruals (Accrual EM) as the difference between firm's total accruals (scaled by total assets) and NA.

As proxy for analysts' guidance we use the model developed and validated by Matsumoto (2002) which adopts a method similar to the Jones model (Jones, 1991) for computing abnormal accruals. Specifically, we first estimate the expected portion of analysts' forecast by modeling the seasonal change in earnings as a function of i) the prior quarter's seasonal change in earnings and ii) returns cumulated over the current year:

$$
\Delta E P S_{i, j, t, q} / P_{i, j, t, q-4}=\alpha_{j, t}+\beta_{l j, t} *\left(\Delta E P S_{i, j, t, q-1} / P_{i, j, t, q-5}\right)+\beta_{2 j, t} * C R E T_{i, j, t, q}+\varepsilon_{i, j, t, q}
$$

where:

- $\quad \Delta \mathrm{EPS}_{\mathrm{ijtq}}$ is earnings per share for firm $\mathrm{i}$ in four-digit SIC code $\mathrm{j}$ in quarter $\mathrm{q}$ of year $\mathrm{t}$, less earnings per share for the same firm four quarters prior (i.e. quarter $t-4$ ), as reported in $\mathrm{I} / \mathrm{B} / \mathrm{E} / \mathrm{S}$;

- $\quad \mathrm{P}_{\mathrm{ijtq}}$ is price per share for firm $\mathrm{i}$ in four-digit SIC code $\mathrm{j}$ at the end of quarter $\mathrm{q}$ of year $\mathrm{t}$, as reported in quarterly Compustat;

- $\quad$ CRET $_{\mathrm{ijt}}$ is cumulative daily excess returns for firm $\mathrm{i}$ in four-digit SIC code $\mathrm{j}$ in quarter $\mathrm{q}$ of year $\mathrm{t}$ obtained from CRSP. Returns are cumulated from three days after the quarter q-4 earnings announcement to 20 days before the quarter q earnings announcement.

This model is estimated for each firm year using all firm-quarters in that year from the same four-digit SIC code. Since the estimate of analysts' expected forecast should use only data that would be available to analysts in making their forecast, following Matsumoto (2002) we use the parameter estimates from the prior firm-year to determine the expected change in EPS (E[ $\triangle \mathrm{EPS}])$. We then add this value to the earnings from the same quarter in the prior year to obtain the expected forecast (E[F]) of the current quarter's earnings:

$$
\begin{gathered}
E\left[\Delta E P S_{i, j, t, q}\right]=\hat{\alpha}_{j, t-1}+\vec{\beta}_{1 j, t-1} *\left(\Delta E P S_{i, j, t, q-1} / P_{i, j, t, q-5)}+\vec{\beta}_{2 j, t-1} * C R E T_{i, j, t, q}\right] * P_{i, j, t, q-4} \\
E\left[F_{i, j, t, q}\right]=E P S_{i, j, t, q-4}+E\left[\Delta E P S_{i, j, t, q}\right]
\end{gathered}
$$

Subtracting the expected forecast (computed using equation 7) from the last published consensus forecast for the quarter provides the unexpected portion of the forecast (UEF). We then multiply UEF by minus 1 (Analysts' Guidance) so that the higher the amount, the more likely it is that the firm has downward guided analysts' forecasts.

Results are reported in Table 6. Consistent with our main analyses, we find a negative and significant association between CEO's risk incentives and real earnings management only when we use the amount of abnormal discretionary expenditures as a proxy for real earnings management. 
Table 6. Controlling for other earnings game strategies

\begin{tabular}{|c|c|c|c|c|c|c|}
\hline Dependent variable: & R_PROD & R_DISX & R_PROD & R_DISX & R_PROD & R_DISX \\
\hline & \multicolumn{2}{|c|}{ 3SLS } & \multicolumn{2}{|c|}{ 3SLS } & \multicolumn{2}{|c|}{ 3SLS } \\
\hline & (1) & (2) & (3) & (4) & (5) & (6) \\
\hline \multirow[t]{2}{*}{ Accrual EM } & $0.1687 * * *$ & $0.0982 * * *$ & & & $0.1672 * * *$ & $0.0958 * * *$ \\
\hline & [8.484] & {$[4.627]$} & & & {$[8.270]$} & [4.491] \\
\hline \multirow[t]{2}{*}{ Analysts' Guidance } & & & $0.0166^{*}$ & $-0.0191 * *$ & 0.0124 & $-0.0202 * *$ \\
\hline & & & {$[1.876]$} & {$[-2.135]$} & {$[1.411]$} & {$[-2.250]$} \\
\hline \multirow[t]{2}{*}{ Risk Incentives } & 0.0365 & $-0.2185 * * *$ & 0.0544 & $-0.1947 * * *$ & 0.0368 & $-0.1965 * * *$ \\
\hline & {$[0.705]$} & {$[-4.209]$} & {$[1.062]$} & {$[-3.847]$} & {$[0.733]$} & {$[-3.908]$} \\
\hline \multirow[t]{2}{*}{ Equity Incentives } & -0.0051 & $-0.1376^{* * *}$ & 0.0044 & $-0.1243 * * *$ & -0.0053 & $-0.1256^{* * *}$ \\
\hline & {$[-0.190]$} & {$[-5.099]$} & {$[0.167]$} & {$[-4.770]$} & {$[-0.204]$} & {$[-4.842]$} \\
\hline \multirow[t]{2}{*}{ Career Concerns } & $-0.0004 * * *$ & -0.0001 & $-0.0004 * * *$ & -0.0002 & $-0.0004 * * *$ & -0.0002 \\
\hline & {$[-2.684]$} & {$[-0.919]$} & {$[-2.993]$} & {$[-1.166]$} & {$[-2.710]$} & {$[-1.072]$} \\
\hline \multirow[t]{2}{*}{ Log Assets } & -0.0013 & $0.0191 * * *$ & -0.0031 & $0.0171 * * *$ & -0.0014 & $0.0176^{* * *}$ \\
\hline & {$[-0.344]$} & {$[5.065]$} & {$[-0.842]$} & [4.669] & {$[-0.368]$} & [4.777] \\
\hline \multirow[t]{2}{*}{ Cycle } & $-0.0002 * * *$ & $-0.0001 * * *$ & $-0.0002 * * *$ & $-0.0001 * * *$ & $-0.0002 * * *$ & $-0.0001 * * *$ \\
\hline & {$[-10.203]$} & {$[-5.994]$} & {$[-10.359]$} & {$[-6.466]$} & {$[-10.316]$} & {$[-6.421]$} \\
\hline \multirow[t]{2}{*}{ M_B } & $-0.0032 * * *$ & $-0.0025 * * *$ & $-0.0034 * * *$ & $-0.0025 * * *$ & $-0.0033^{* * *}$ & $-0.0025^{* * *}$ \\
\hline & {$[-11.315]$} & {$[-7.985]$} & {$[-11.608]$} & {$[-8.242]$} & {$[-11.236]$} & {$[-7.934]$} \\
\hline \multirow[t]{2}{*}{ Z Score } & $0.0006^{* * *}$ & $0.0009 * * *$ & $0.0004 * *$ & $0.0009 * * *$ & $0.0006^{* * *}$ & $0.0010 * * *$ \\
\hline & {$[3.121]$} & [4.163] & {$[2.274]$} & [4.311] & {$[3.068]$} & [4.802] \\
\hline \multirow[t]{2}{*}{ Market Share } & $0.0581 * * *$ & $0.0851^{* * *}$ & $0.0573 * * *$ & $0.0812^{* * *}$ & $0.0590 * * *$ & $0.0808 * * *$ \\
\hline & [5.892] & {$[8.220]$} & [5.935] & [8.196] & {$[6.230]$} & [8.167] \\
\hline \multirow[t]{2}{*}{ NOA } & $0.0626^{* * *}$ & $0.0989 * * *$ & $0.0660 * * *$ & $0.1004 * * *$ & $0.0626^{* * *}$ & $0.0978 * * *$ \\
\hline & [10.963] & [16.337] & [11.240] & [16.591] & [11.056] & [16.421] \\
\hline \multirow[t]{2}{*}{ Tenure Auditor } & 0.0002 & $0.0008^{* * *}$ & 0.0001 & $0.0008^{* * *}$ & 0.0001 & $0.0008^{* * *}$ \\
\hline & {$[0.924]$} & [4.910] & {$[0.789]$} & [4.679] & {$[0.921]$} & {$[4.660]$} \\
\hline \multirow[t]{2}{*}{ ROA } & $-0.5951 * * *$ & $-0.3182 * *$ & $-0.4212 * * *$ & -0.2009 & $-0.5869 * * *$ & $-0.2773 * *$ \\
\hline & {$[-4.519]$} & {$[-2.383]$} & {$[-3.322]$} & {$[-1.592]$} & {$[-4.426]$} & {$[-2.072]$} \\
\hline \multirow[t]{2}{*}{ Tenure CEO } & $0.0061 * * *$ & $0.0038 * *$ & $0.0058 * * *$ & $0.0039 * *$ & $0.0061 * * *$ & $0.0041 * *$ \\
\hline & [3.539] & [2.058] & {$[3.325]$} & [2.107] & {$[3.543]$} & [2.233] \\
\hline Year Dummies & YES & YES & YES & YES & YES & YES \\
\hline Quarter Dummies & YES & YES & YES & YES & YES & YES \\
\hline Industry Dummies & YES & YES & YES & YES & YES & YES \\
\hline Observations & 4.470 & 4.470 & 4.470 & 4.470 & 4.470 & 4.470 \\
\hline
\end{tabular}

Note. The table reports 3SLS results for equations A simultaneously estimated with equations B (untabulated). Accrual EM is signed discretional accruals computed using the Modified Jones Model; Analysts' Guidance is the unexpected portion of analysts' forecast computed as in Matsumoto (2002) multiplied by - 1. Variables are defined in Appendix B. *, **, *** indicate statistical significance at 10\%, 5\%, 1\% level, respectively. P-values are two tailed. z-statistics in brackets.

\section{Conclusions}

In this paper we investigate whether CEO's risk incentives affect the firm's decision to engage in real earnings management. Because risk adverse CEOs are likely to accept less risk than that accepted by diversified shareholders (Fama \& French, 1992), companies use option compensation to motivate managers to take risk (Jensen \& Meckling, 1976). Nonetheless, risk taking has an intrinsic cost because not all risks produce the 
expected benefits. Therefore, given CEO risk incentives, real earnings management can be viewed as a tool to avoid the undesirable consequences of risk on reported earnings, such as large losses. However, engaging in real earnings management requires cutting investments, such as $\mathrm{R} \& \mathrm{D}$, that have a well-documented association with firm's future risk profile (Comin \& Philippon, 2005). As a consequence, whether CEOs incentivized on risk use real earnings management to mitigate the intrinsic costs of the risk-taking activity is an empirical question that we tackle in this paper. Using a sample of quarterly observations from US firms over the period 2003-2010, and an instrumental variable approach to overcome endogeneity concerns, we show that CEOs with high risk-related incentives engage less in real activity manipulations that encompass cutting discretionary expenditures than do executives with low incentives. These findings are consistent with the idea that CEOs incentivized on risk avoid engaging in real management activities that can decrease firm's future risk profile. Like all studies, ours is not without its limitations. Specifically, when interpreting our results it is important to remember that the use of an instrumental variable approach can only mitigate concerns about endogeneity without providing a definitive solution since the identification of appropriate instruments relies on strong assumptions that might not hold.

\section{References}

Adut, D., Holder, A. D., \& Robin, A. (2013). Predictive versus opportunistic earnings management, executive compensation, and firm performance. Journal of Accounting and Public Policy, 32, 126-146. http://dx.doi.org/10.1016/j.jaccpubpol.2013.02.007

Altman, E. (2000). Predicting financial distress of companies: Revisiting the Z-Score and ZETA models. New York University Working Paper. Retrieved from http://people.stern.nyu.edu/ealtman/Zscores.pdf

Armstrong, C. S., Larcker, D. F., Ormazabal, G., \& Taylor, D. J. (2013). The relation between equity incentives and misreporting: The role of risk-taking incentives. Journal of Financial Economics, 109, 327-350. http://dx.doi.org/10.1016/j.jfineco.2013.02.019

Bartov, E., \& Cohen, D. A. (2009). The "numbers game" in the pre- and post- Sarbanes-Oxley eras. Journal of Accounting, Auditing \& Finance, 24, 505-534. http://dx.doi.org/10.1177/0148558X0902400401

Bartov, E., Givoly, D., \& Hayn, C. (2002). The rewards to meeting or beating earnings expectations. Journal of Accounting and Economics, 33, 173-204. http://dx.doi.org/10.1016/S0165-4101(02)00045-9

Bergstresser, D., \& Philippon, T. (2006). CEO incentives and earnings management. Journal of Financial Economics, 80, 511-529. http://dx.doi.org/10.1016/j.jfineco.2004.10.011

Black, F., \& Scholes, M. (1973). The pricing of options and corporate liabilities. The Journal of Political Economy, 81, 637-654. http://www.jstor.org/stable/1831029

Bozzolan, S., Fabrizi, M., Mallin, C. A., \& Michelon, G. (2015). Corporate Social Responsibility and Earnings Quality: International Evidence. The International Journal of Accounting, 50, 361-396. http://dx.doi.org/10.1016/j.intacc.2015.10.003

Brown, L. D., \& Caylor, M. L. (2005). A temporal analysis of quarterly earnings thresholds: Propensities and valuation consequences. The Accounting Review, 80, 423-440. http://dx.doi.org/10.2308/accr.2005.80.2.423.

Carlson, S. J., \& Bathala, C. T. (1997). Ownership differences and firms' income smoothing behaviour. Journal of Business Finance and Accounting, 24, 179-196. http://dx.doi.org/10.1111/1468-5957.00101

Cheng, Q., \& Warfield, T. D. (2005). Equity incentives and earnings management. The Accounting Review, 80, 441-476. http://dx.doi.org/10.2308/accr.2005.80.2.441

Choi, J. S., Kwak, Y. M., \& Choe, C. (2014). Earnings Management Surrounding CEO Turnover: Evidence from Korea. Abacus, 50, 25-55. http://dx.doi.org/10.1111/abac.12021

Cohen, D. A., \& Zarowin, P. (2010). Accrual-based and real earnings management activities around seasoned

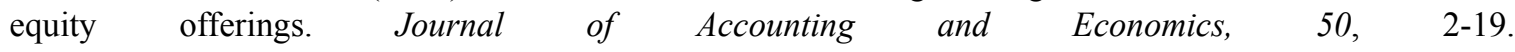
http://dx.doi.org/10.1016/j.jacceco.2010.01.002

Cohen, D. A., Dey, A., \& Lys, T. (2008). Real and accrual-based earnings management in the pre- and $\begin{array}{llll}\text { post-Sarbanes-Oxley periods. The Accounting Review, 83, } & \text { 757-787. }\end{array}$ http://dx.doi.org/10.2308/accr.2008.83.3.757

Cohen, D. A., Pandit, S., Wasley, C. E., \& Zach, T. (2011). Measuring real activity management. SSRN Working Paper. Retrieved from http://ssrn.com/abstract=1792639

Coles, J. L., Daniel, N. D., \& Naveen, L. (2006). Managerial incentives and risk-taking. Journal of Financial Economics, 79, 431-468. http://dx.doi.org/10.1016/j.jfineco.2004.09.004 
Comin, D., \& Philippon, T. (2005). The rise in firm-level volatility: Causes and consequences. NBER Macroeconomics Annual, 20, 167-228. Retrieved from http://www.nber.org/papers/w11388

Core, J. E., Guay, W., \& Larcker, D. F. (2003). Executive equity compensation and incentives: A survey. Economic Policy Review, 9, 27-50. http://dx.doi.org/10.1016/j.jfineco.2004.09.004

Core, J., \& Guay, W. (2002). Estimating the value of employee stock option portfolios and their sensitivities to price and volatility. Journal of Accounting Research, 40, 613-630. http://dx.doi.org/http://www.jstor.org/stable/3542266

Das, S., Hong, K., \& Kim, K. (2013). Earnings smoothing, cash flow volatility, and CEO cash bonus. Financial Review, 48, 123-150. http://dx.doi.org/10.1111/j.1540-6288.2012.00349.x

Dechow, P. M. (1994). Accounting earnings and cash flows as measures of firm performance: The role of accounting accruals. Journal of Accounting and Economics, 18, 3-42. http://dx.doi.org/10.1016/0165-4101(94)90016-7

Dechow, P. M., Kothari, S. P., \& Watts, R. (1998). The relation between earnings and cash flows. Journal of Accounting and Economics, 25, 133-168. http://dx.doi.org/10.1016/S0165-4101(98)00020-2

Degeorge, F., Patel, J., \& Zeckhauser, R. (1999). Earnings management to exceed thresholds. Journal of Business, 72, 1-33. http://www.jstor.org/stable/10.1086/209601

Duellman, S., Ahmed, A. S., \& Abdel-Meguid, A. M. (2013). An empirical analysis of the effects of monitoring intensity on the relation between equity incentives and earnings management. Journal of Accounting and Public Policy, 32, 495-517. http://dx.doi.org/10.1016/j.jaccpubpol.2013.08.007

Fabrizi, M., Mallin, C., \& Michelon, G. (2014). The role of CEO's personal incentives in driving corporate social responsibility. Journal of Business Ethics, 124, 311-326. http://dx.doi.org/10.1007/s10551-013-1864-2

Fama, E., \& French, K. (1992). The cross-section of expected stock returns. The Journal of Finance, 47, 427-465. http://dx.doi.org/ 10.1111/j.1540-6261.1992.tb04398.x

Fredrickson, J. W., Hambrick, D. C., \& Baumrin, S. (1988). A model of CEO dismissal. Academy of Management Review, 13, 255-270. http://dx.doi.org/10.5465/AMR.1988.4306882

Ge, W., \& Kim, J. B. (2014). Real earnings management and the cost of new corporate bonds. Journal of Business Research, 67, 641-647. http://dx.doi.org/10.1016/j.jbusres.2013.01.021

Gong, J. J., \& Li, S. (2013). CEO incentives and earnings prediction. Review of Quantitative Finance and Accounting, 40, 647-674. http://dx.doi.org/10.1007/s11156-012-0291-2

Graham, J. R., Harvey, C. R., \& Rajgopal, S. (2005). The economic implications of corporate financial reporting. Journal of Accounting and Economics, 40, 3-73. http://dx.doi.org/10.1016/j.jacceco.2005.01.002

Grant, J., Markarian, G., \& Parbonetti, A. (2009). CEO risk-related incentives and income smoothing. Contemporary Accounting Research, 26, 1029-1065. http://dx.doi.org/10.1506/car.26.4.2

Jensen, M., \& Meckling, W. (1976). Theory of the firm: Managerial behaviour, agency costs, and ownership structure. Journal of Financial Economics, 3, 305-360. http://dx.doi.org/10.1016/0304-405X(76)90026-X

Jones, J. (1991). Earnings management during import relief investigations. Journal of Accounting Research, 29 , 193-229. http://www.jstor.org/stable/2491047

Khalil, M., \& Simon, J. (2014). Efficient contracting, earnings smoothing and managerial accounting discretion. Journal of Applied Accounting Research, 15, 100-123. http://dx.doi.org/10.1108/JAAR-06-2012-0050

Kim, J. B., \& Sohn, B. C. (2013). Real earnings management and cost of capital. Journal of Accounting and Public Policy, 32, 518-543. http://dx.doi.org/10.1016/j.jaccpubpol.2013.08.002

Kothari, S. P., Leone, A. J., \& Wasley, C. E. (2005). Performance matched discretionary accrual measures. Journal of Accounting and Economics, 39, 163-197. http://dx.doi.org/10.1016/j.jacceco.2004.11.002

Kuang, Y. F., Qin, B., \& Wielhouwer, J. L. (2014). CEO Origin and Accrual-Based Earnings Management. Accounting Horizons, 28, 605-626. http://dx.doi.org/10.2308/acch-50810

Matsumoto, D. A. (2002). Management's incentives to avoid negative earnings surprises. The Accounting Review, 77, 483-514. http://dx.doi.org/10.2308/accr.2002.77.3.483

Merton, R. C. (1973). Theory of rational option pricing. The Bell Journal of Economics and Management 
Science, 4, 141-183. http://www.jstor.org/stable/3003143

Murphy, K. J. (1999). Executive compensation. Handbook of Labor Economics, 3, 2485-2563.

Rogers, D. A. (2002). Does executive portfolio structure affect risk management? CEO risk-taking incentives and corporate derivatives usage. Journal of Banking and Finance, 26, 271-295. http://dx.doi.org/10.1016/S0378-4266(01)00222-9

Rogers, D. A. (2005). Managerial risk-taking incentives and executive stock option repricing: A study of US $\begin{array}{llll}\text { casino } & \text { Fecutives. } & \text { Financial }\end{array}$ http://dx.doi.org/10.1111/j.1755-053X.2005.tb00093.x

Ronen, J., \& Sadan, S. (1981). Smoothing income numbers: Objectives and implications. Reading, MA: Addison-Wesley.

Roychowdhury, S. (2006). Earnings management through real activities manipulation. Journal of Accounting and Economics, 42, 335-370. http://dx.doi.org/10.1016/j.jacceco.2006.01.002

Zang, A. Y. (2012). Evidence on the trade-off between real activities manipulation and accrual-based earnings management. The Accounting Review, 87, 675-703. http://dx.doi.org/10.2308/accr-10196

\section{Notes}

Note 1. Non-monetary incentives are those incentives that do not stem from the executive's compensation structure and are not linked to a monetary reward.

Note 2. Following Zang (2012), we do not examine abnormal cash flows from operations because real activities manipulation impacts it in various directions, and the net effect is ambiguous (see also Roychowdhury, 2006).

Note 3. Since we are using quarterly data, we follow Bartov and Cohen (2009) in focusing on selling and general and administrative (SG\&A) expenses that are available on a quarterly basis. In Compustat, quarterly SG\&A expenditures also include R\&D investments.

Note 4. Appendix A reports the formula used to compute the sensitivity of individual stock options to changes in stock price.

Note 5. Cash compensation is defined as the sum of base salary and annual bonuses.

Note 6. We excluded firm i from the computation. Note that since our instruments are computed for each year/industry combination, we cannot include fixed effects in equations (B).

Note 7. Following Matsumoto (2002), for firms that report a balance for PPE in the fourth fiscal quarter but report missing data in quarters 1-3, we compute the year-to-year change in PPE and add to each of the interim quarters a proportional amount of this change based on the proportion of annual depreciation incurred in that quarter.

\section{Appendix A}

\section{Estimates of a stock option's sensitivity to stock price}

Estimates of a stock option's sensitivity to stock price are calculated based on the Black-Scholes (1973) formula for valuing European call options, as modified to account for dividend payout by Merton (1973).

$$
\text { Option value }=\left[\mathrm{S} e^{-\mathrm{i} T} \mathrm{~N}(\mathrm{Z})-\mathrm{X}^{e^{-\gamma T}} \mathrm{~N}\left(\mathrm{Z}-\sigma \mathrm{T}^{(1 / 2}\right)\right]
$$

Where

$\mathrm{Z}=\left[\ln (\mathrm{S} / \mathrm{X})+\mathrm{T}\left(\mathrm{r}-\mathrm{d}+\sigma^{2} / 2\right] / \sigma \mathrm{T}^{(1 / 2)}\right.$;

$\mathrm{N}=$ cumulative probability function for the normal distribution;

$\mathrm{S}=$ price of the underlying stock;

$\mathrm{X}=$ exercise price of the option;

$\sigma=$ expected stock-return volatility over the life of the option;

$\mathrm{r}=$ risk-free interest rate;

$\mathrm{d}=$ expected dividend yield over the life of the option; 
The sensitivity with respect to a $1 \%$ change in stock price is defined as:

$$
\delta(\text { option value }) / \delta(p r i c e)] *(\text { price } / 100)=e^{-d T} * N(Z) *(p r i c e / 100)
$$

The sensitivity with respect to a 0.01 change in stock price volatility is defined as:

$$
\delta \text { (option value) } / \delta(\text { volattitty) }] * 0.01=e d F^{2} * N^{t}(Z) * s^{*} 1^{1 / 2} * 0.01
$$

Where $\mathrm{N}^{\prime}$ is the normal density function.

\section{Appendix B}

\section{Variable definition}

- $\quad$ R_PROD = abnormal production costs computed as in Roychowdhury (2006).

- R_DISX = abnormal discretionary expenses multiplied by - 1, computed as in Roychowdhury (2006).

- $\quad$ Real EM = sum of R_DISX and R_PROD.

- $\quad$ Risk Incentives = Vega of CEO's stock options divided by their Delta.

- Equity Incentives = dollar change in the value of CEO's stock and option holdings that would come from a one percentage point increase in the company stock price, standardized by cash compensation.

- $\quad$ Career Concerns $=$ CEO's age multiplied by -1 .

- $\quad$ Log Assets = natural logarithm of total assets.

- $\quad$ Cycle $=$ length of the operating cycle computed as in Dechow (1994).

- $\quad$ M_B = market value of equity divided by the book value of equity.

- $\quad$ Z Score = Altman's (2000) Z-score.

- $\quad$ Market Share = firm's market share computed as the ratio of a company's total sales to the total sales of its three-digit SIC code industry in a given year-quarter.

- $\quad \mathrm{NOA}=$ firm's net operating assets (i.e. shareholders' equity less cash and marketable securities plus total debt) standardized by total assets.

- $\quad$ Tenure Auditor $=$ number of years the auditor has audited the firm.

- $\quad \mathrm{ROA}=$ operating profits divided by total assets.

Tenure CEO = dummy variable that takes the value of 1 if the CEO's tenure is greater or equal to 3, zero otherwise.

\section{Copyrights}

Copyright for this article is retained by the author(s), with first publication rights granted to the journal.

This is an open-access article distributed under the terms and conditions of the Creative Commons Attribution license (http://creativecommons.org/licenses/by/3.0/). 